\title{
In situ estimation of indigestible compounds contents in cattle feed and feces using bags made from different textiles ${ }^{1}$
}

\section{Tiago Neves Pereira Valente ${ }^{2}$, Edenio Detmann ${ }^{3}$, Sebastião de Campos Valadares Filho ${ }^{3}$, Maura da Cunha ${ }^{4}$, Augusto César de Queiroz ${ }^{3}$, Cláudia Batista Sampaio ${ }^{2}$}

1 Trabalho conduzido com apoio do CNPq, FAPEMIG (PPM) e INCT-Ciência Animal.

2 Programa de Pós-graduação em Zootecnia - UFV. Bolsista do CNPq.

${ }^{3}$ Departamento de Zootecnia, UFV, Viçosa-MG. Pesquisador do CNPq e do INCT-Ciência Animal.

${ }^{4}$ Laboratório de Biologia Celular e Tecidual, UENF, Campos dos Goytacazes-RJ. Pesquisadora do CNPq.

ABSTRACT - The objective of this experiment was to evaluate estimates of concentration of indigestible dry matter (iDM), indigestible neutral detergent fiber (iNDF) and indigestible acid detergent fiber (iADF) in samples of cattle feed and feces processed at different particle sizes (1-, 2-, and 3-mm) using bags made from nylon (50 $\mu \mathrm{m}$ ), F57 (Ankom ${ }^{\circledR}$ ), and nonwoven textile (NWT $-100 \mathrm{~g} / \mathrm{m}^{2}$ ) in a in situ evaluation procedure. Eight samples of concentrates, seven samples of forages and two samples of cattle feces were used. The samples were put in the bags according to a ratio of $20 \mathrm{mg}$ of dry matter/cm² of surface by using three bags of each textile for each size of particle, totaling 405 bags, which were submitted to ruminal incubation for 264 hours. The contents of indigestible compounds in the samples were evaluated sequentially. Blank bags were used for microscopic evaluation of textile physical integrity and for evaluation of the physical resistance. The presence of contaminants caused high variability of results of iDM, indicating that its using as internal marker should not be recommended. By using the textiles F57 and NWT, similar estimates for contents of iNDF and iADF were obtained whereas by using nylon $(50 \mu \mathrm{m})$, the concentration of iNDF was underestimated, possibly because of loss of particles due to its porosity. Nylon presented loss of resistance in all analytical stages, expanding its probality of rupture, especially after extraction with acid detergent. For in situ evaluation of indigestible compounds, it is suggested grinding samples in 2-mm screen sieves.

Key Words: F57, internal markers, nylon, non-woven textile, particle size

\section{Estimação in situ dos componentes indigestíveis em alimentos e fezes de bovinos com sacos de diferentes tecidos}

RESUMO - Objetivou-se avaliar as estimativas de concentração de matéria seca (MSi), fibra em detergente neutro (FDNi) e fibra em detergente ácido (FDAi) indigestíveis em amostras de alimentos e fezes bovinas processadas em diferentes tamanhos de partículas (1, 2 e $3 \mathrm{~mm}$ ) utilizando-se sacos confeccionados com os tecidos nylon (50 $\mu \mathrm{m}$ ), F57 (Ankom ${ }^{\circledR}$ ) e tecido não-tecido (TNT - $100 \mathrm{~g} / \mathrm{m}^{2}$ ) em procedimento de avaliação in situ. Foram utilizadas oito amostras de alimentos concentrados, sete de alimentos volumosos e duas de fezes bovinas. O material foi acondicionado nos sacos numa relação de $20 \mathrm{mg}$ de matéria seca/ $\mathrm{cm}^{2}$ de superfície utilizando-se três sacos de cada tecido para cada tamanho de partícula, totalizando 405 sacos, que foram submetidos a incubação ruminal durante 264 horas. Os teores dos compostos indigestíveis nas amostras foram avaliados sequencialmente. Sacos em branco foram utilizados para avaliação microscópica da integridade física dos tecidos e para avaliação da resistência à tração. A presença de contaminantes causou alta variabilidade dos resultados de MSi, o que indica comprometimento de sua aplicação como indicador interno. Utilizando os tecidos F57 e TNT obtiveram-se estimativas similares para os teores de FDNi e FDAi, enquanto com o tecido nylon $(50 \mu \mathrm{m})$ a concentração de FDNi foi subestimada, possivelmente em decorrência da perda de partículas devido à sua porosidade. O nylon apresentou perda de resistência em todas as etapas analíticas, o que amplia sua probabilidade de ruptura, principalmente após extração com detergente ácido. Para procedimentos in situ de avaliação de compostos indigestíveis, sugere-se a moagem de amostras em peneiras com porosidade de $2 \mathrm{~mm}$.

Palavras-chave: F57, indicadores internos, nylon, tamanho de partículas, tecido não-tecido 


\section{Introduction}

Internal markers are inherent components of feeds that can be used to estimate digesta flow and fecal mass in digestion assays with ruminant animals. Currently, the most used internal markers are: indigestible dry matter (iDM), indigestible neutral detergent fiber (iNDF), and indigestible acid detergent fiber (iADF) (Detmann et al., 2004).

The capacity to be completely recovered in feces or any segment of gastrointestinal tract is one of the demanded characteristics for an ideal marker (Owens \& Hanson, 1992). Under the lack of such characteristic, the estimates of fecal excretion or digesta flow could be biased. In a theoretical point of view, the recovering capacity is inherent to the marker (Detmann et al., 2007); however, indirect influences of methods applied to estimate its content in samples can apparently bias the estimates of marker recovering (Freitas et al., 2002; Detmann et al., 2007).

When internal markers contents are evaluated using in situ procedures, different textiles can be used to make incubation bags. Among those, it can be highlighted the nylon $(50 \mu \mathrm{m})$, the F57 (Ankom ${ }^{\circledR}$ ) and the non-woven textile (NWT $-100 \mathrm{~g} / \mathrm{m}^{2}$ ). Nylon could be assumed as standard textile for rumen incubation procedures. However, controversial results have been reported with regard to its efficiency for obtaining contents of indigestible compounds, which seem to be associated with significant loss of particles (Casali et al., 2009).

Considering that different textiles can be used for in situ estimation of indigestible compounds contents, there is an imminent demand for results regarding accuracy and precision of estimates and for aspects concerning analytical costs and operational facilities.

The objective of this work was to evaluate the contents of iDM, iNDF and iADF in samples of feeds and cattle feces processed at different particle sizes and using bags made from nylon (50 $\mu \mathrm{m}), \mathrm{F} 57$ and NWT through in situ procedures.

\section{Material and Methods}

The experiment was carried out in the Laboratório de Nutrição Animal of the Departamento de Zootecnia at the Universidade Federal de Viçosa, Viçosa, MG. Samples of concentrates (sorghum grain, corn gluten meal, citrus pulp, cottonseed meal, soybean meal, wheat bran, corn grain and soybean hulls) and forages (signal grass hay, sugarcane, coast cross hay, corn straw, corn silage and elephant grass cut at 50 and 250 days of regrowth) were used. Feces samples taken from cattle fed $15 \%$ and $50 \%$ concentrate diets, on dry matter (DM) basis, were also evaluated. Those feces samples were named low (LC) and high (HC) concentrate feces, respectively.

The samples of corn silage, sugarcane, elephant grass (50 and 250 days) and feces were oven-dried $\left(60^{\circ} \mathrm{C}\right)$ and together other samples were processed in a knife mill to pass through 1-, 2- and 3-mm screen sieves. The corn gluten meal sample was evaluated only at $1-\mathrm{mm}$ because it was acquired in this form from the manufacturer. Additionally, the samples of sorghum grain, cottonseed meal, citrus pulp and soybean meal were only processed at 1- and 2-mm sieves. The sorghum grains were small enough to pass in the whole form through 3-mm sieve. On the other hand, cottonseed meal, citrus pulp and soybean meal were manufactured at $2-\mathrm{mm}$ and could not be evaluated at 3-mm.

Chemical evaluations were performed by using samples processed at 1-mm. The contents of DM, organic matter $(\mathrm{OM})$ and crude protein $(\mathrm{CP})$ were evaluated according to Silva \& Queiroz (2002). The contents of neutral detergent fiber (NDF) and acid detergent fiber (ADF) were evaluated using the detergent compositions recomended by Mertens (2002) and Goering \& Van Soest (1975), respectively. The micro-extraction in autoclave was used (Pell \& Schofield, 1993) (Table 1). The NDF analysis was conducted using a heat-stable $\alpha$-amilase (Termamyl 2X, Novozymes), but not sodium sulfite. There were no ash or protein corrections.

For the evaluation of iDM, iNDF and iADF contents, bags of $4 \times 5 \mathrm{~cm}$ were manufactured using nylon $(50 \mu \mathrm{m})$ and non-woven textile (NWT - $100 \mathrm{~g} / \mathrm{m}^{2}$ ). The F57 bags were bought directly from the manufacturer $\left(\right.$ Ankom ${ }^{\circledR}$ ). Three bags of each textile in each particle size were evaluated, totaling 405 bags. The samples were put in the bags following the ratio of $20 \mathrm{mg} \mathrm{DM} / \mathrm{cm}^{2}$ of surface (Nocek, 1988). For all experimental procedures, the bags were heat-sealed.

The bags were incubated in the rumen of three crossbred Holstein $\times$ Zebu lactating cows. The animals were fed a mixed diet (70:30 corn silage:concentrate ratio). It was used one bag of each sample and particle size by cow. The samples were kept in the rumen for 264 hours (Casali et al., 2008). After that, the bags were cleaned with tap water, oven-dried $\left(60^{\circ} \mathrm{C} / 72\right.$ hours and $105^{\circ} \mathrm{C} / 1$ hour $)$ sequentially, put in a dissecator and then weighed, obtaining then the iDM content.

The procedures to evaluate iNDF and iADF contents were performed by using a fiber analyzer $\left(\right.$ Ankom $\left.^{220}\right)$. The neutral and acid detergent were produced according to Mertens (2002) and Goering \& Van Soest (1975). The detergent:sample ratio was $100 \mathrm{~mL} / \mathrm{g}$ DM using 1 hour as extraction time. 
Table 1 - Chemical composition of feed and feces

\begin{tabular}{|c|c|c|c|c|c|}
\hline \multirow[b]{2}{*}{ Material } & \multicolumn{5}{|c|}{ Item $^{1}$} \\
\hline & $\begin{array}{c}\text { Dry matter } \\
(\%)\end{array}$ & $\begin{array}{l}\text { Organic matter } \\
\text { (\% of dry matter) }\end{array}$ & $\begin{array}{l}\text { Crude protein } \\
\text { (\% of dry matter) }\end{array}$ & $\begin{array}{l}\text { Neutral detergent } \\
\text { fiber ( } \% \text { of dry matter) }\end{array}$ & $\begin{array}{l}\text { Acid detergent } \\
\text { fiber ( } \% \text { of dry matter) }\end{array}$ \\
\hline Sorghum grain & 88.54 & 99.11 & 8.68 & 11.61 & 3.15 \\
\hline Corn gluten meal & 90.76 & 99.03 & 63.48 & 12.85 & 6.43 \\
\hline Citrus pulp & 85.76 & 94.21 & 5.40 & 25.56 & 17.31 \\
\hline Cottonseed meal & 89.28 & 92.53 & 39.93 & 27.92 & 15.36 \\
\hline Soybean meal & 89.39 & 93.20 & 43.07 & 13.49 & 6.48 \\
\hline Wheat bran & 83.59 & 93.18 & 14.95 & 47.74 & 14.18 \\
\hline Corn grain & 86.28 & 98.65 & 8.25 & 13.61 & 2.64 \\
\hline Soybean hulls & 89.77 & 95.96 & 10.83 & 67.34 & 44.62 \\
\hline Signal grass hay & 90.54 & 96.59 & 3.71 & 86.29 & 50.29 \\
\hline Sugarcane & 22.28 & 96.33 & 2.90 & 60.41 & 37.34 \\
\hline Coast cross hay & 89.96 & 94.41 & 11.43 & 83.93 & 40.44 \\
\hline Corn straw & 90.43 & 98.50 & 1.88 & 90.80 & 45.55 \\
\hline Corn silage & 30.97 & 93.06 & 4.49 & 57.79 & 29.37 \\
\hline Elephant Grass (50 days) & 13.55 & 92.17 & 9.07 & 74.35 & 51.88 \\
\hline Elephant Grass (250 days) & 22.54 & 93.54 & 7.20 & 85.34 & 53.67 \\
\hline Feces (low concentrate) & 13.37 & 88.83 & 8.88 & 66.03 & 36.44 \\
\hline Feces (high concentrate) & 14.66 & 91.07 & 10.51 & 54.20 & 24.08 \\
\hline
\end{tabular}

After neutral detergent extraction, the bags were sequentially washed with hot distilled water and acetone, oven-dried $\left(60^{\circ} \mathrm{C} / 72\right.$ hours following $105^{\circ} \mathrm{C} / 1$ hour $)$, put in a dissecator and then weighed obtaining the iNDF. The iADF analysis was sequentially performed using the same procedures used for iNDF evaluation.

Before incubation procedures, all bags were cleaned with boiling neutral detergent, oven-dried and weighed as described before to obtain the blank weights.

Eight bags of each textile (blank bags) were used to evaluate the physical integrity after different analytical steps. Duplicates of bags were submitted to the following procedures: A) cleaning with neutral detergent (textile before incubation); B) all procedures described in A plus 264 hours of rumen incubation, cleaning with tap water and oven-drying $\left(60^{\circ} \mathrm{C} / 72\right.$ hours and $105^{\circ} \mathrm{C} / 1$ hour $)$; C) all procedures described in $\mathrm{B}$ plus neutral detergent extraction $\left(100^{\circ} \mathrm{C} / 1\right.$ hour), washing with hot water and acetone and oven-drying as described above; and D) all procedures described in C plus acid detergent extraction $\left(100^{\circ} \mathrm{C} / 1\right.$ hour $)$, washing with hot water and acetone and oven-drying as previously described. Such sequence of procedures was adopted to simulate the sequential evaluation of iDM, iNDF and iADF, respectively.

Aliquots of textiles were taken from one bag in each experimental stage and submitted to scanning microscopic evaluation (Silveira, 1998). Textile fragments were fixed on metallic holders by using a glue containing silver. After that, the textiles were covered with a gold layer and evaluated at 30 and $100 \times$ of augment using a scanning microscope (DSEM 962, Zeiss Co.). These procedures were performed in the Laboratório de Biologia Celular e Tecidual at the Centro de Biociências e Biotecnologia of the Universidade Estadual do Norte Fluminense, Campos dos Goytacazes, RJ.

To evaluate the tensile capacity (tension of rupture), one bag of each textile and experimental stage was sent to the Laboratório de Ensaios Físicos e de Composição of SENAI/CETIQT (Rio de Janeiro, RJ). It was used a dynamometer Instron (model 4467) according to the characteristics: speed of the claw - $100 \mathrm{~mm} / \mathrm{min}$, distance between claws $-3 \mathrm{~cm}$, and sizes of the claws $-2.5 \times 7.5 \mathrm{~cm}$. That evaluation was done according to technical norm NBR 13041/ISO 9073 (part3).

The contents of iDM, iNDF and iADF were evaluated independently for each material (sample) by using a variance analysis according to a $3 \times 3$ factorial arrangement, with three textiles and three particle sizes. This last factor (particle sizes) was not constant among materials as previously reported in this section. The analysis of variance was conducted using type III sums of squares because of imbalances due to the lost of some bags. When necessary, the means were compared by using the Tukey-Kramer test (Littell et al., 1991). All statistical procedures were performed by using SAS $(\alpha=0.05)$

\section{Results and Discussion}

There was no interaction of textile and particle size ( $P>0.05)$, except for iDM and iNDF evaluated in HC feces $(\mathrm{P}<0.05)$.

For most materials, it was observed similar iDM contents when NWT and F57 were used ( $\mathrm{P}>0.05$ ), being those contents higher than those obtained with nylon $(\mathrm{P}<0.05)$. Different 
results were obtained for citrus pulp, wheat bran, corn grain and coast cross hay, where all textiles were found different from each other $(\mathrm{P}<0.05)$, being the lower estimates verified by using nylon. There was no difference among textiles $(\mathrm{P}>0.05)$ concerning iDM contents in corn gluten meal (Table 2).

On the other hand, for all materials (except corn grain), there were similar iNDF contents $(\mathrm{P}>0.05)$ when NWT and F57 were used; but both textiles produced higher estimates compared to nylon (Tables 3 and 5). For corn grain, all textiles were found different $(\mathrm{P}<0.05)$; however, iNDF estimates obtained with F57 and NWT were closer when compared to estimates obtained with nylon (Table 3).

There are no estimates of iADF contents using nylon because all bags presented rupture during extraction with acid detergent. Despite this, such as observed for iNDF, similar estimates $(\mathrm{P}>0.05)$ of iADF contents were obtained using NWT and F57 for all materials, except for corn grain (Table 4).

Generally, it was observed higher variability among textiles for iDM contents (Table 2) when compared to iNDF and iADF (Tables 3 and 4).

Table 2 - Means and coefficients of variation of indigestible dry matter contents (\% of dry matter) in samples processed at different particle sizes and using different textile bags

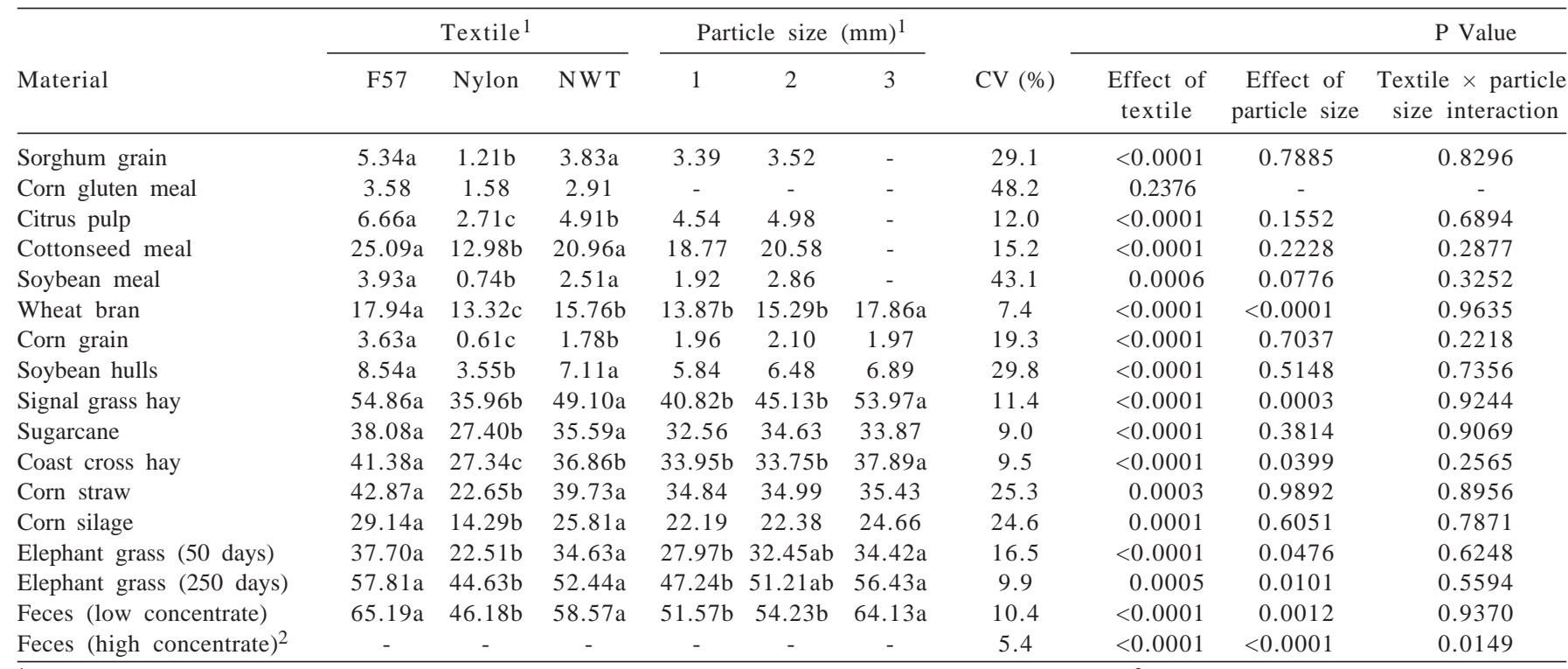

${ }^{1}$ Means followed by different letters within textiles or particle sizes are different according to Tukey-Kramer test $(\mathrm{P}<0.05) .{ }^{2}$ See evaluation of interaction effect in Table 5 .

Table 3 - Means and coefficients of variation of indigestible neutral detergent fiber (\% of dry matter) in samples processed at different particle sizes and using different textile bags

\begin{tabular}{|c|c|c|c|c|c|c|c|c|c|c|}
\hline \multirow[b]{2}{*}{ Material } & \multicolumn{3}{|c|}{ Textile $^{1}$} & \multicolumn{3}{|c|}{ Particle size $(\mathrm{mm})^{1}$} & \multirow[b]{2}{*}{ CV (\%) } & \multicolumn{3}{|c|}{ P Value } \\
\hline & $\mathrm{F} 57$ & Nylon & NWT & 1 & 2 & 3 & & $\begin{array}{l}\text { Effect of } \\
\text { textile }\end{array}$ & $\begin{array}{c}\text { Effect of } \\
\text { particle size }\end{array}$ & $\begin{array}{c}\text { Textile } \times \text { particle } \\
\text { size interaction }\end{array}$ \\
\hline Sorghum grain & $2.90 \mathrm{a}$ & $0.55 b$ & $2.56 \mathrm{a}$ & 1.88 & 2.13 & - & 45.7 & 0.0016 & 0.5731 & 0.9490 \\
\hline Corn gluten meal & $1.61 \mathrm{a}$ & $0.18 \mathrm{~b}$ & $1.36 \mathrm{a}$ & - & - & - & 37.5 & 0.0093 & - & - \\
\hline Citrus pulp & $4.58 a$ & $2.01 \mathrm{~b}$ & $4.08 \mathrm{a}$ & 3.48 & 3.64 & - & 11.1 & $<0.0001$ & 0.4362 & 0.3937 \\
\hline Cottonseed meal & $14.02 \mathrm{a}$ & $10.57 b$ & $14.51 \mathrm{a}$ & 12.76 & 13.31 & - & 11.2 & 0.0010 & 0.4362 & 0.6737 \\
\hline Soybean meal & $2.04 \mathrm{a}$ & $0.16 b$ & $1.88 \mathrm{a}$ & $1.15 b$ & $1.58 \mathrm{a}$ & - & 27.3 & $<0.0001$ & 0.0296 & 0.1215 \\
\hline Wheat bran & $15.11 \mathrm{a}$ & 11.33b & $14.00 \mathrm{a}$ & $12.06 \mathrm{~b}$ & $12.88 b$ & $15.50 \mathrm{a}$ & 7.4 & $<0.0001$ & $<0.0001$ & 0.9192 \\
\hline Corn grain & $1.70 \mathrm{a}$ & $0.19 \mathrm{c}$ & $1.13 \mathrm{~b}$ & 0.97 & 1.11 & 0.93 & 24.5 & $<0.0001$ & 0.2558 & 0.4319 \\
\hline Soybean hulls & $5.40 \mathrm{a}$ & $2.74 b$ & $5.04 \mathrm{a}$ & 3.67 & 4.70 & 4.81 & 26.0 & 0.0004 & 0.1019 & 0.7215 \\
\hline Signal grass hay & $48.65 a$ & $30.91 b$ & $44.07 a$ & $35.00 \mathrm{~b}$ & $39.88 b$ & $48.75 a$ & 14.2 & $<0.0001$ & 0.0008 & 0.9173 \\
\hline Sugarcane & $33.06 a$ & $24.56 b$ & $30.34 a$ & $27.27 \mathrm{~b}$ & $30.25 a b$ & $30.44 a$ & 7.8 & $<0.0001$ & 0.0254 & 0.7082 \\
\hline Coast cross hay & $35.48 a$ & $23.49 b$ & 31.99a & 29.34 & 28.91 & 32.71 & 10.8 & $<0.0001$ & 0.0693 & 0.1711 \\
\hline Corn straw & $37.14 \mathrm{a}$ & $17.04 b$ & $34.46 a$ & 28.16 & 30.70 & 29.77 & 26.7 & 0.0002 & 0.8120 & 0.8809 \\
\hline Corn silage & $23.27 \mathrm{a}$ & $10.34 b$ & $21.92 \mathrm{a}$ & 17.38 & 17.67 & 20.48 & 29.2 & 0.0009 & 0.4801 & 0.8505 \\
\hline Elephant grass (50 days) & $28.42 \mathrm{a}$ & $17.38 b$ & $29.38 a$ & $21.06 \mathrm{~b}$ & $25.80 \mathrm{ab}$ & $28.32 \mathrm{a}$ & 18.7 & $<0.0001$ & 0.0133 & 0.4742 \\
\hline Elephant grass (250 days) & $51.85 a$ & $40.40 \mathrm{~b}$ & $47.91 \mathrm{a}$ & $42.05 b$ & $45.95 a b$ & $52.16 \mathrm{a}$ & 10.9 & 0.0016 & 0.0047 & 0.5996 \\
\hline Feces (low concentrate) & $53.22 \mathrm{a}$ & $36.82 b$ & $49.61 \mathrm{a}$ & $41.25 b$ & $44.47 \mathrm{~b}$ & $53.94 a$ & 11.8 & $<0.0001$ & 0.0006 & 0.7465 \\
\hline Feces (high concentrate) ${ }^{2}$ & - & - & - & - & - & - & 5.7 & $<0.0001$ & $<0.0001$ & 0.0321 \\
\hline
\end{tabular}

${ }^{1}$ Means followed by different letters within textiles or particle sizes are different according to Tukey-Kramer test (P<0.05). ${ }^{2}$ See evaluation of interaction effect in Table 5 . 
Table 4 - Means and coefficients of variation of indigestible acid detergent fiber (\% of dry matter) in samples processed at different particle sizes and using different textile bags

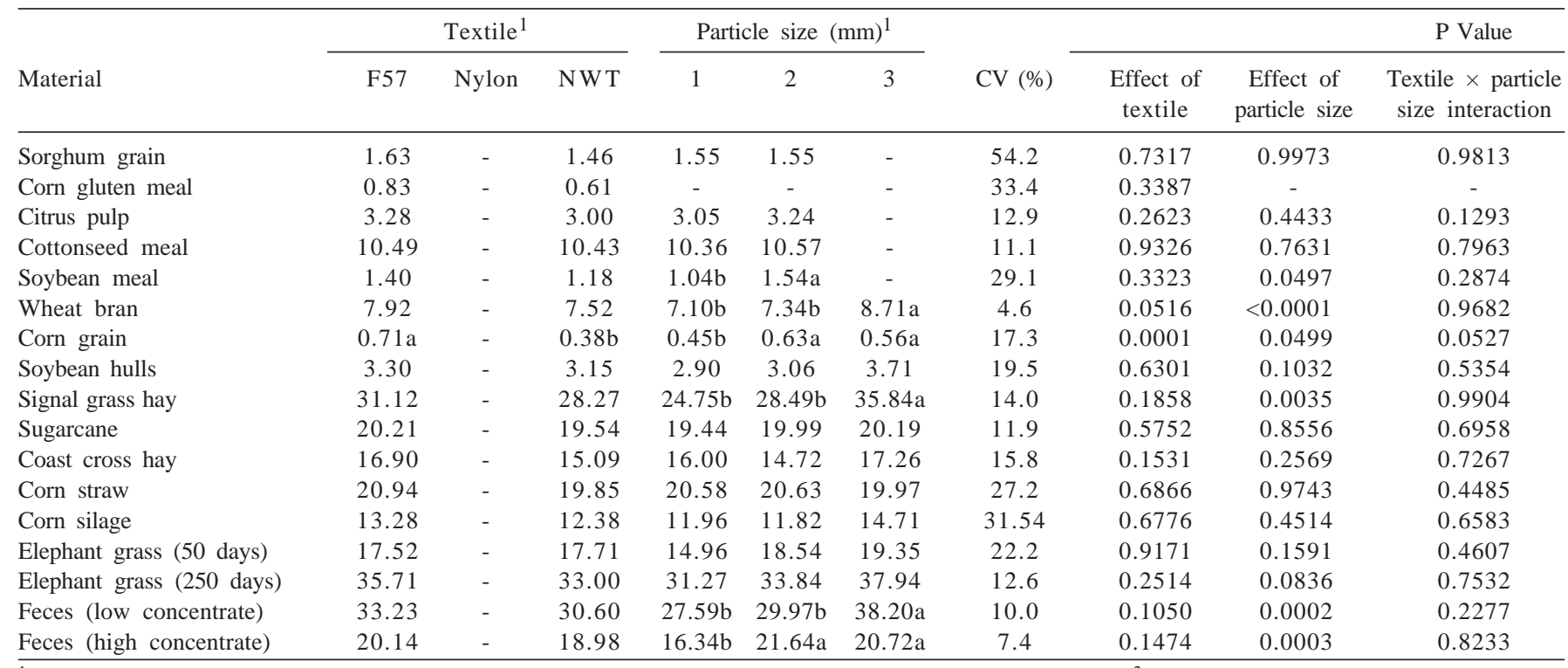

${ }_{1}^{1}$ Means followed by different letters within textiles or particle sizes are different according to Tukey-Kramer test $(\mathrm{P}<0.05) .{ }^{2}$ See evaluation of interaction effect in Table 5 .

Table 5 - Evaluation of interaction of textile and particle size on contents of indigestible dry matter and indigestible neutral detergent fiber in sample of feces taken from cattle fed high concentrate diet

\begin{tabular}{cccc}
\hline \multirow{2}{*}{$\begin{array}{l}\text { Particle } \\
\text { size }(\mathrm{mm})^{1}\end{array}$} & \multicolumn{3}{c}{ Textile $^{1}$} \\
\cline { 2 - 4 } & F57 & Nylon & $\mathrm{NWT}$ \\
\hline & Indigestible dry matter $(\%$ of dry matter $)$ \\
2 & $43.67 \mathrm{Ba}$ & $21.77 \mathrm{Bc}$ & $35.67 \mathrm{Bb}$ \\
3 & $54.37 \mathrm{Aa}$ & $25.95 \mathrm{ABb}$ & $50.37 \mathrm{Aa}$ \\
& $56.02 \mathrm{Aa}$ & $31.94 \mathrm{Ab}$ & $49.08 \mathrm{Aa}$ \\
& & & \\
2 & Indigestible neutral detergent & fiber $(\%$ of dry & matter $)$ \\
3 & 30.83Ba & $16.45 \mathrm{Bb}$ & $30.38 \mathrm{Ba}$ \\
& $40.51 \mathrm{Aa}$ & $19.82 \mathrm{ABb}$ & $38.16 \mathrm{Aa}$ \\
& $40.17 \mathrm{Aa}$ & $24.96 \mathrm{Ab}$ & $36.42 \mathrm{Aa}$ \\
\hline
\end{tabular}

${ }^{1}$ Means in the row, followed by different lower case letters, or in the column, followed by different capital letters, are different according to Tukey-Kramer test $(\mathrm{P}<0.05)$.

Some authors have suggested using iDM as internal marker in ruminant nutrition research (Huhtanen et al., 1994; Detmann et al., 2001), which could be advantageous because of the low analytical cost compared to indigestible fibrous residues (Detmann et al., 2001). However, the presence of contaminants may compromise the results (Huhtanen et al., 1994; Casali et al., 2009) because detergents are not used to clean the residues after incubation and the withdrawal of microbial debris through anionic action become limited (Van Soest, 1994; Clipes et al., 2006). Additionally, the detergent action could contribute to decrease the contamination by non-microbial residues (e.g. feed or rumen content particles), that are normally observed outside of bags after removal from the rumen.
The contamination by residues in the in situ evaluation of iDM seems to be not constant among different materials (Casali et al., 2008) and possibly is not homogeneous among replicates (Sampaio et al., 2011). Thereby, at least part of the differences among textiles concerning the iDM contents could be confounded with variations in the levels of microbial and non-microbial contaminants. This pattern may cause inconsistencies on inferences and indicates that iDM should not be used as internal marker.

Considering the results of iNDF and iADF (Tables 2 and 3 ), it can be assumed that estimates obtained with both F57 and NWT could be considered equivalent. The difference between these textiles for corn grain is supposed to be random or casual because it was one single difference among seventeen materials and any apparent cause could be associated with that pattern. Similar results between F57 and NWT were reported by Casali et al. (2009) and Valente et al. (2011), who worked with in situ evaluation of iNDF and laboratorial evaluation of NDF, respectively.

The lower contents of iNDF observed with nylon (Tables 2 and 5) could be associated with loss of insoluble particles through its mesh (Figure 1). Such argument is corroborated by results of other authors (Casali et al., 2009; Valente et al., 2011).

The geometrically regular arrangement of nylon mesh (Figures 1 e 2) allows the output of fibrous particles in laboratorial evaluation of NDF (Valente et al., 2011). That pattern can become more prominent when samples are submitted to long term incubations in the rumen (Casali et al., 2009), causing underestimation of the 

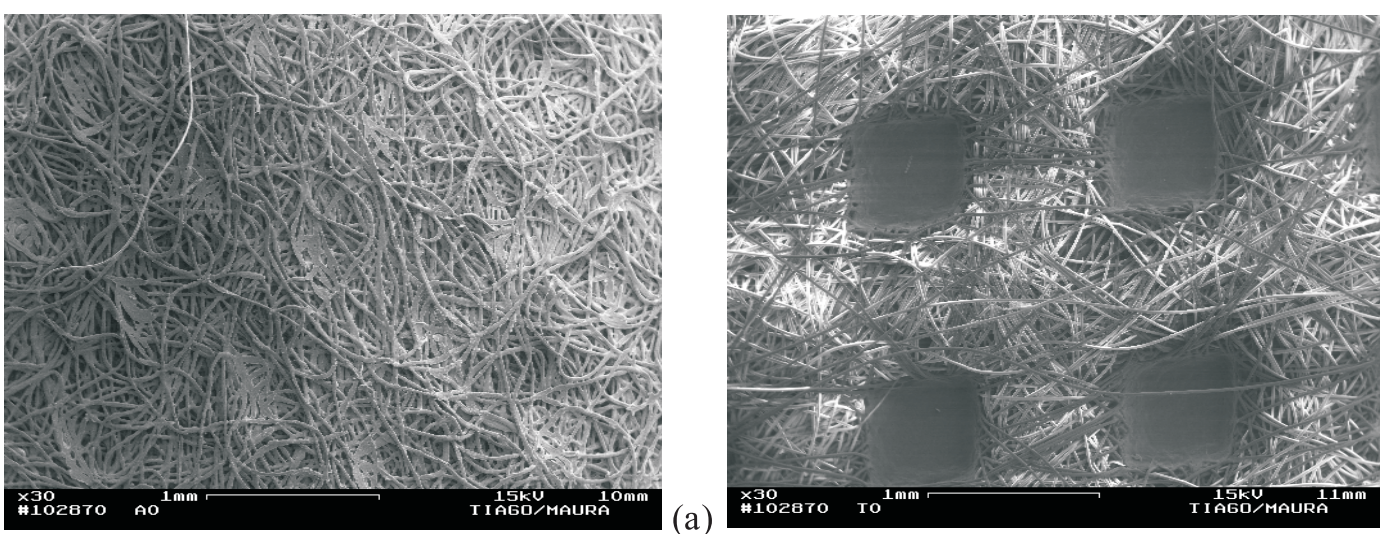

(b)

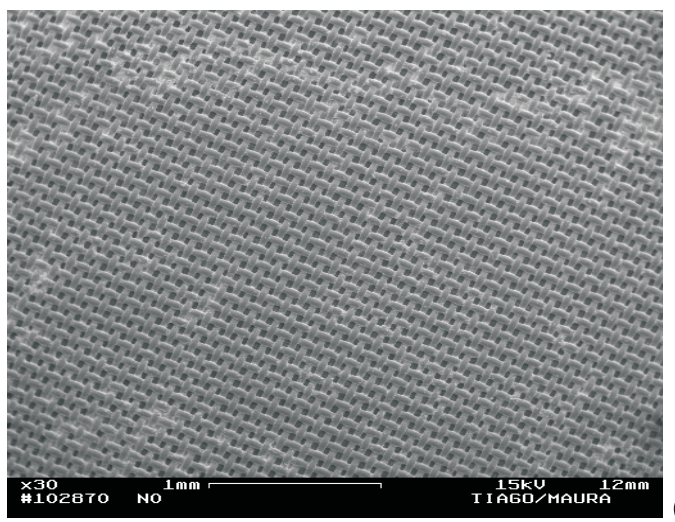

(c)

Figure 1 - Photomicrographs of F57 (a), NWT (b) and nylon textiles (30×).
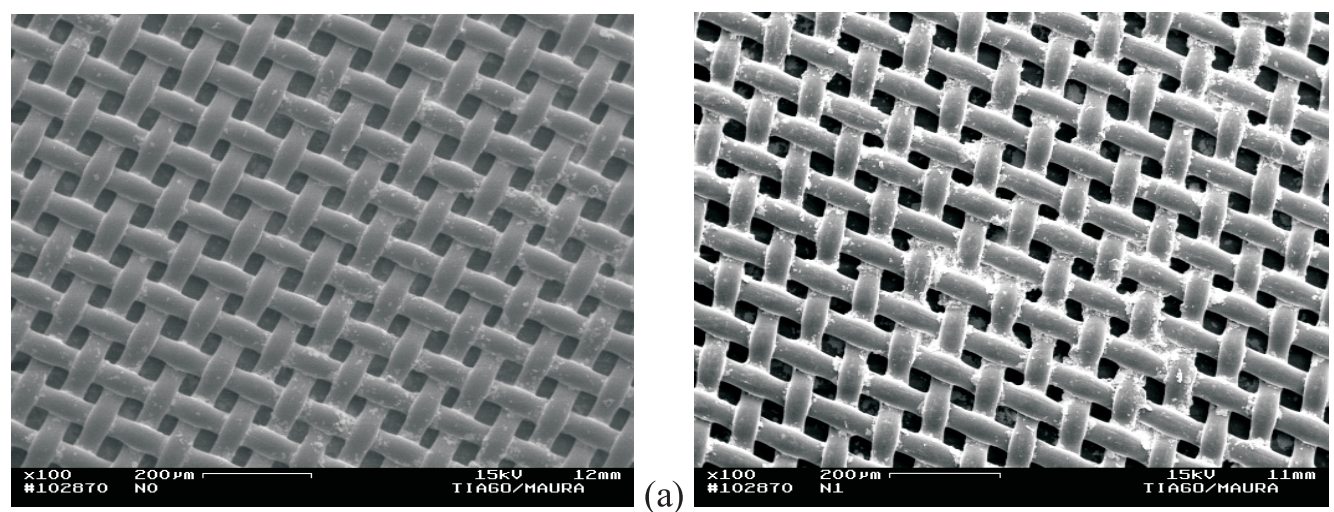

(b)
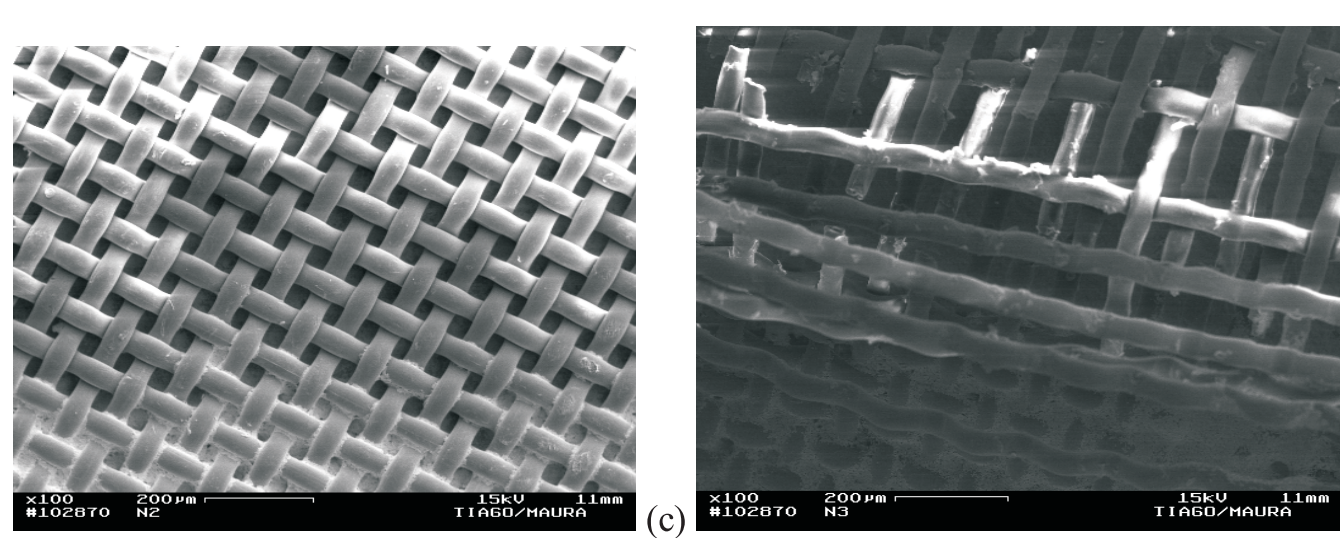

Figure 2 - Photomicrographs of nylon textile (100×) (a - before incubation; b - after ruminal incubation; c - after sequential extraction with neutral detergent; $\mathrm{d}$ - after sequential extraction with acid detergent). 
contents of indigestible compounds. Accordingly, the utilization of nylon for in situ evaluation of indigestible compounds is not recommended.

The superficial structure of F57 (Figure 3) and NWT (Figure 4) are similar and both present irregular geometrical arrangement, being formed by deposition of synthetic fiber without weaving. From this, it could be inferred that their porosities are apparently smaller than those of nylon (Figure 2). However, the NWT does not present homogenous porosity along all surface because part of the textile is heat-sealed during textile manufacturing (Figure 1). Theoretically, this characteristic should reduce the effective porous surface of NWT. However, this fact does not seem to constraint the inflow of microorganisms as well as the outflow of degraded material, which is a desirable characteristic (Nozière \& Michalet-Doreau, 2000). This observation is based on the fact that iNDF and iADF estimates using NWT were similar to those obtained with F57 (Tables 3 and 4).

On the other hand, the lower porosity of NWT and F57 could compromise the removal of fermentation gases from the bag, which could limit the microbial assessment to the sample and, as consequence, the degradation (Udén et al., 1974). So, the inner bag gas accumulation could be used as an argument to support the higher estimates of iNDF obtained with F57 and NWT (Table 3).

However, such interferences could be considered signficant only at short incubation times (Lindberg \& Knutsson, 1981, cited by Udén \& Van Soest, 1984). Thereby, the influence of gas accumulation can not overestimate the contents of indigestible residues obtained with long term incubations (Casali et al., 2009), such as the ones used in this study. Once more, it is emphasized that loss of particles is the main constraint on accuracy of estimates of indigestible compounds obtained by using nylon.

There were effects of particles size $(\mathrm{P}<0.05)$ on eight and six materials regarding iNDF and iADF contents, respectively (Tables 3, 4 and 5). The iDM results were not examined because of the possible confounding with contaminants, as discussed before. For all materials, it was observed higher estimates for 3-mm particles compared to 1-mmparticles $(\mathrm{P}<0.05)$.

The 2-mm particles presented varied results. Contents of iNDF obtained with 2-mm particles were similar to 1-mm particles $(\mathrm{P}>0.05)$, but lower $(\mathrm{P}<0.05)$ than 3 -mm particles for wheat bran, signal grass hay and LC feces; similar to 3-mm $(\mathrm{P}>0.05)$ but higher $(\mathrm{P}<0.05)$ than $1-\mathrm{mm}$ for $\mathrm{HC}$ feces (considering only F57 and NWT); or similar to 1-mm and
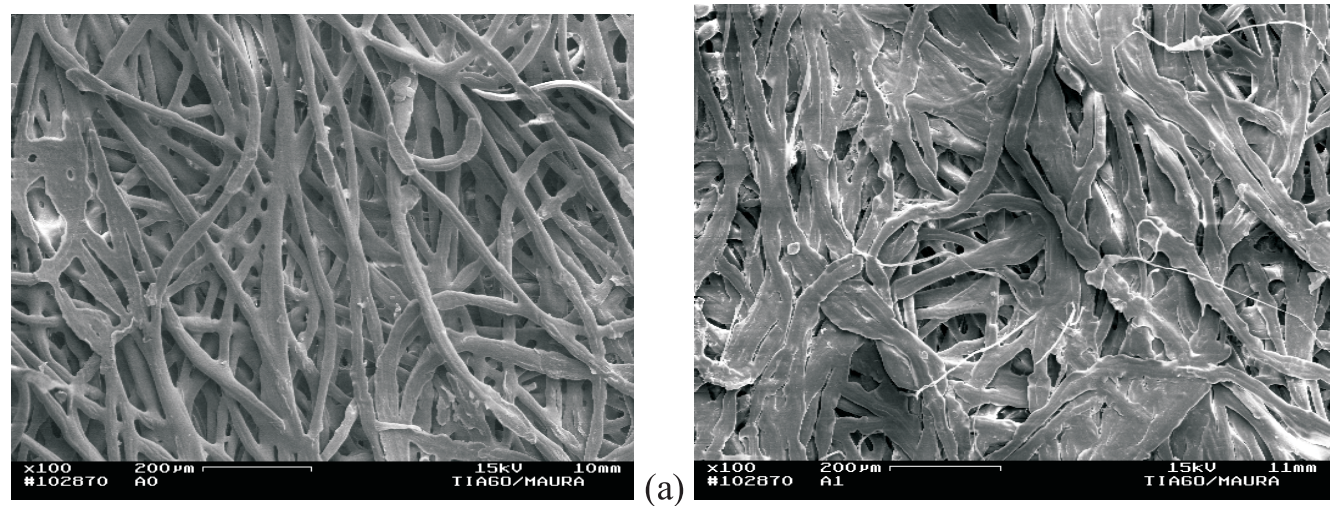

(b)
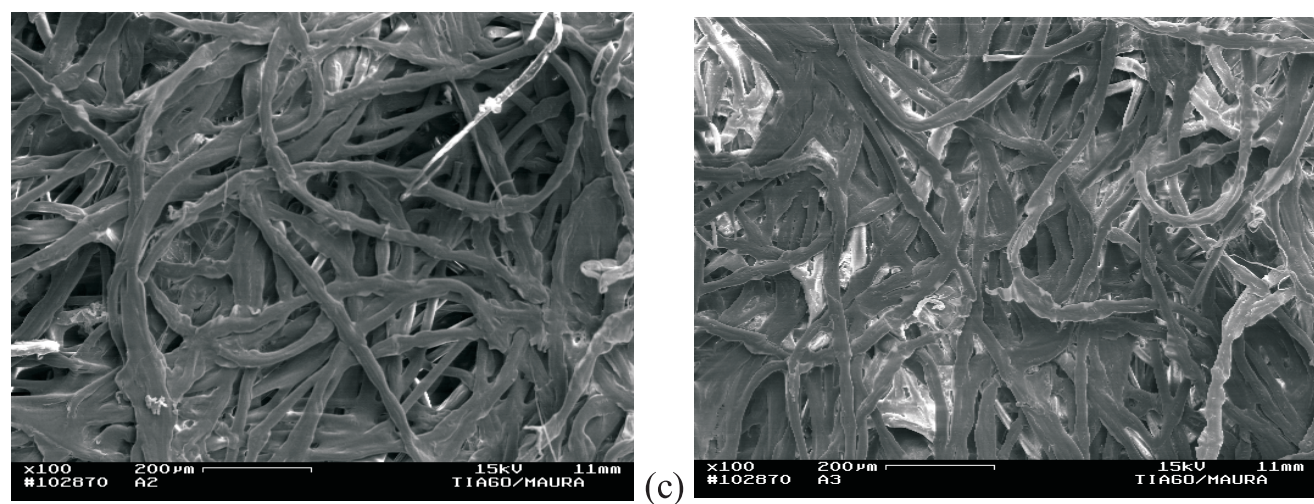

(d)

Figure 3 - Photomicrographs of F57 textile (100x) (a - before incubation; b-after ruminal incubation; c-after sequential extraction with neutral detergent; $\mathrm{d}$ - after sequential extraction with acid detergent). 

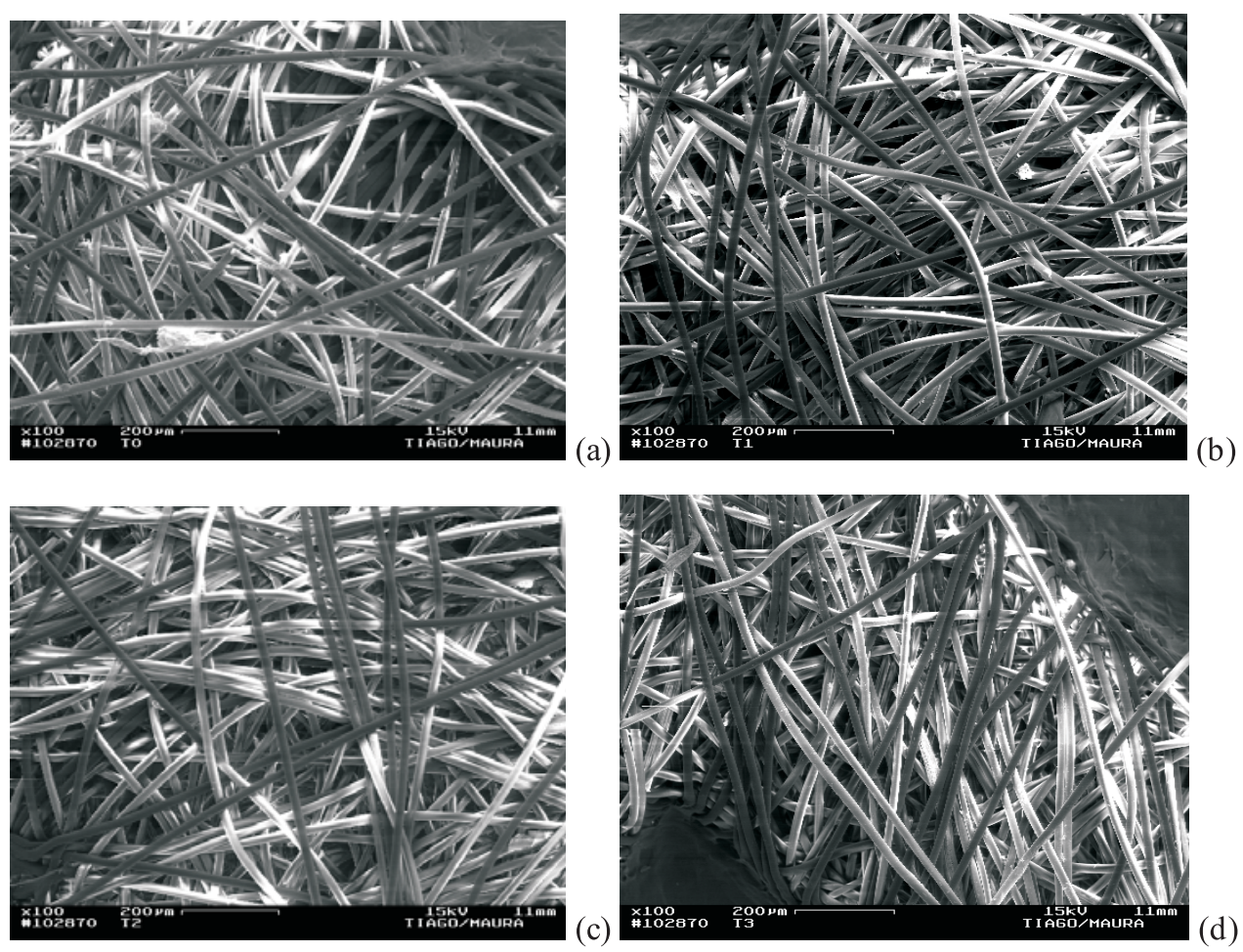

Figure 4 - Photomicrographs of NWT textile (100×) (a - textile before incubation; b - after ruminal incubation; c - after sequential extraction with neutral detergent; $\mathrm{d}$ - after sequential extraction with acid detergent).

3-mm ( $\mathrm{P}>0.05)$ presenting a intermediate position in multiple comparison procedure for sugarcane and elephant grass (Tables 3 and 5). Contents of iADF obtained with 2-mm particles were similar to $1-\mathrm{mm}(\mathrm{P}>0.05)$, but lower $(\mathrm{P}<0.05)$ than 3-mm for wheat bran, signal grass hay and LC feces; or similar to 3-mm $(\mathrm{P}<0.05)$, but higher $(\mathrm{P}<0.05)$ than 1 -mm for corn grain and HC feces (Table 4). For soybean meal it was observed differences $(\mathrm{P}<0.05)$ between the two evaluated particles sizes (1- and 2-mm) for iNDF as well as iADF.

The lack of standardization constitutes one of the limitations for correct applying in situ procedures (Vanzant et al., 1998; Broderick \& Cochran, 2000). Different particles sizes are used in such procedures (Bowman \& Firkins, 1993; Nocek \& Kohn, 1988). Screen sieves of 2-mm and 5-mm were suggested by Nocek (1988) for concentrate and forage as an approach to compensate the lack of rumination on samples. However, big particles can compromise the microbial access to the substrate (Nozière \& Michaelet-Doreau, 2000). Therefore, the utilization of 5 -mm particles for forage evaluation has not been recommended in more recent approaches (Hvelplund \& Weisbjerg, 2000; NRC, 2001).

On the other hand, the high variability of particles sizes effect among different materials seems to be supported on variability of true distribution of particles sizes of a sample after griding, which can be different for each material (forage or concentrate) (Nozière \& Michaelet-Doreau, 2000). When some materials are ground using a 1-mm screen sieve, very thin particles can be produced, which can escape through textile pores before degradation. This pattern could overestimate the degraded fraction and, as consequence, underestimate the non-degraded residue.

Despite of heterogeneity among materials, the utilization of particles ground to pass a 2-mm screen sieve seems to propitiate an equilibrium point between control of particles loss and an adequate specific surface for microbial degradation. This approach could be assumed as current recommendation for in situ procedures of feed evaluation (Vanzant et al., 1998; Nozière \& Michaelet-Doreau, 2000; NRC, 2001).

Although laboratorial extraction with detergents demands 1-mm particles for efficient extraction of soluble compounds, mainly with neutral detergent, such requirement does not compromise the evaluation of fibrous residues obtained with long term incubations, because it was not expected significant concentrations of cell contents in the incubation residue (Valente et al., 2011). Thereby, the extraction with neutral and acid detergents can be assuredly done on residues obtained after incubation of 2-mm particles.

The evaluation of tensile capacity showed that F57 was not affected by any procedure. The values of tension of rupture were approximately constant after all experimental 
Table 6 - Tension of rupture (kgf) of different textile bags according to experimental stage

\begin{tabular}{lrr}
\hline & \multicolumn{2}{c}{ Tecido } \\
\cline { 2 - 3 } Experimental stage & F57 & T N T \\
\hline Before incubation & 30.16 & 35.26 \\
After ruminal incubation & 31.47 & 24.57 \\
After ruminal incubation and neutral detergent extraction & 32.38 & 27.38 \\
After ruminal incubation and sequential extraction with neutral detergent and acid detergent & 31.72 & 22.36 \\
\hline
\end{tabular}

stages (Table 6). Such pattern can be corroborated by visual survey of that textile (Figure 3).

On the other hand, the NWT presented decrease in tension of rupture after ruminal incubation; although the values had remained stable after detergent extractions (Table 6). When bags are submitted to long term ruminal incubations, the textile can lose resistance because the rumen continuous contractions submit the bags to tension all the time. That decrease in resistance seems to occur despite of no alterations in physical structure of textile, as observed in this study (Figure 4). Such pattern brings into evidence that NWT is not altered by chemical extractions with detergents but it can be physically affected by long term incubation in the rumen. However, that decrease in resistance during ruminal incubation does not seem to cause significant loss of particles because estimates obtained with NWT were similar to those ones obtained using F57 (Tables 3 e 4). Neverthless, it seems to indicate that reutilization of NWT for a second ruminal incubation could lead to increase in the probability of bag rupture, what possibly would not be observed for F57.

Nylon presented the lower tension of rupture when compared to the other textiles. Additionally, this textile was affected by all experimental procedures (Table 6).
Therefore, it may be affirmed that, besides lower resistance, nylon is subjected to damages caused by physical, chemical and biological events. So, there will be high probability of rupture along all analytical steps. The gradual decrease in physical resistance culminates in the rupture of fibers (Figure 2) and loss of all bags during acid detergent extraction (Table 7). Similar results were found by Senger et al. (2008), who reported that polyamides are not resistant to hot acid detergent solutions. Such pattern can compromise the accuracy of estimates and increases the experimental labor because the samples should be taken off the bags for acid detergent extraction.

There was a small loss of F57 and NWT bags during experimental procedures. Additionally, such losses should be assumed as casual because it could not be found any cause to explain that (Table 7).

According to the results of this work, it could be concluded that NWT $\left(100 \mathrm{~g} / \mathrm{m}^{2}\right)$ can be a lower cost alternative to F57 for estimating indigestible compounds contents. According to Casali et al. (2009), the estimates obtained using NWT and F57 are generally similar with respect to accuracy and precision. However, the lower cost of NWT (US\$ 0.02/bag) when compared to F57 (US\$2.00/ bag) must be seen as a benefit of NWT utilization, even considering that F57 could be used twice.

Table 7 - Cumulative loss of bags after sequential procedures for estimating indigestible compounds contents

\begin{tabular}{|c|c|c|c|c|c|c|c|c|c|}
\hline \multirow[b]{2}{*}{ Item } & \multicolumn{3}{|c|}{ Ruminal incubation } & \multicolumn{3}{|c|}{ Extraction with neutral detergent } & \multicolumn{3}{|c|}{ Extraction with acid detergent } \\
\hline & F57 & Nylon & NWT & F57 & Nylon & NWT & F57 & Nylon & NWT \\
\hline Lost bags & 3 & 4 & 1 & 3 & 11 & 2 & 3 & 135 & 3 \\
\hline$\%$ loss & 2.2 & 3.0 & 0.7 & 2.2 & 8.2 & 1.5 & 2.2 & 100.0 & 2.2 \\
\hline
\end{tabular}

\section{Conclusions}

The F57 (Ankom ${ }^{\circledR}$ ) and non-woven textile $\left(100 \mathrm{~g} / \mathrm{m}^{2}\right.$ ) propitiate similar estimates of indigestible compounds contents in feeds and cattle feces. The use of nylon (50 $\mu \mathrm{m})$ underestimates the contents of such compounds because there is a significant loss of particles due to its porosity and low physical resistance. For in situ evaluation of indigestible compounds, it is suggested grinding samples as to pass a 2-mm screen sieve.

\section{References}

BOWMAN, J.G.P.; FIRKINS, J.L. Effects of forage species and particle size on bacterial cellulolytic activity and colonization in situ. Journal of Animal Science, v.71, p.1623-1633, 1993.

BRODERICK, G.A.; COCHRAN, R.C. In vitro and in situ methods for estimating digestibility with reference to protein degradability. In: THEODOROU, M.K.; FRANCE, J. (Eds.). Feeding systems and feed evaluation models. Wallingford: CAB International, 2000. p.53-85.

R. Bras. Zootec., v.40, n.3, p.666-675, 2011 
CASALI, A.O.; DETMANN, E.; VALADARES FILHO, S.C. et al. Influência do tempo de incubação e do tamanho de partículas sobre os teores de compostos indigestíveis em alimentos e fezes bovinas obtidos por procedimentos in situ. Revista Brasileira de Zootecnia, v.37, p.335-342, 2008.

CASALI, A.O.; DETMANN, E.; VALADARES FILHO, S.C. et al. Estimação de teores de componentes fibrosos em alimentos para ruminantes em sacos de diferentes tecidos. Revista Brasileira de Zootecnia, v.38, p.130-138, 2009.

CLIPES, R.C.; DETMANN, E.; COELHO DA SILVA, J.F. et al. Evaluation of acid detergent insoluble protein as an estimator of rumen non-degradable protein in tropical grass forages. Arquivo Brasileiro de Medicina Veterinária e Zootecnia, v.58, p.694-697, 2006.

DETMANN, E.; PAULINO, M.F.; ZERVOUDAKIS, J.T. et al. Cromo e indicadores internos na determinação do consumo de novilhos mestiços, suplementados, a pasto. Revista Brasileira de Zootecnia, v.30, p.1600-1609, 2001.

DETMANN, E.; VALADARES FILHO, S.C.; PAULINO, M.F. et al. Avaliação da técnica dos indicadores na estimação do consumo por ruminantes em pastejo. Cadernos Técnicos de Veterinária e Zootecnia, v.46, p.40-57, 2004.

DETMANN, E.; SOUZA, A.L.; GARCIA, R. et al. Avaliação do vício de "tempo longo" de indicadores internos em ensaio de digestão com ruminantes. Arquivo Brasileiro de Medicina Veterinária e Zootecnia, v.59, p.182-188, 2007.

FREITAS, D.; BERCHIELLI, T.T.; SILVEIRA, R.N. et al. Produção fecal e fluxo duodenal de matéria seca e matéria orgânica estimados através de indicadores. Revista Brasileira de Zootecnia, v.31, p.1521-1530, 2002.

GOERING, H.K.; Van SOEST, P.J. Forage fiber analyses (apparatus, reagents, procedures and some applications). Washington, DC: USDA-ARS, 1975. 20p. (Agriculture Handbook, 379).

HUHTANEN, P.; KAUSTELL, K.; JAAKKOLA, S. The use of internal markes to predict total digestibility and duodenal flow of nutrients in cattle given six different diets. Animal Feed Science and Technology, v.48, p.211-227, 1994.

HVELPLUND, T.; WEISBJERG, M.R. In situ techniques for the estimation of protein degradability and post rumen availability In: GIVENS, D.I.; OWEN, E.; AXFORD, R.F.E. et al. (Eds.) Forage evaluation in ruminant nutrition. London: $C A B$ International, 2000. p.233-258.

LITTELL, R.C.; FREUND, R.J.; SPECTOR, P.C. SAS system for linear models. Cary: SAS Institute Inc., 1991. 329p.

MERTENS, D.R. Gravimetric determination of amylase-treated neutral detergent fiber in feeds with refluxing in beaker or crucibles: collaborative study. Journal of AOAC International, v.85, p.1217-1240, 2002

NOCEK, J.E. In situ and other methods to estimate ruminal protein and energy digestibility: a review. Journal of Dairy Science, v.71, p.2051-2069, 1988.
NOCEK, J.E.; KOHN, R.A. In situ particle size reduction of alfafa and timothy hay as influence by form and particle size. Journal of Dairy Science, v.71, p.932-945, 1988.

NOZIÈRE, P.; MICHALET-DOREAU, B. In sacco methods. In: D'MELLO, J.P.F. (Ed.) Farm animal metabolism and nutrition. London: CAB International, 2000. p.233-253.

NATIONAL RESEARCH COUNCIL - NRC. Nutrient requirements of dairy cattle. 7.ed. Washington, DC: Academic Press, 2001. $381 \mathrm{p}$.

OWENS, F.N.; HANSON, C.F. External and internal markers for appraising site and extent of digestion in ruminants. Journal of Dairy Science, v.75, p.2605-2617, 1992.

PELL, A.N.; SCHOFIELD, P. Computerized monitoring of gas production to measure forage digestion in vitro. Journal of Dairy Science, v.76, p.1063-1073, 1993.

SAMPAIO, C.B.; DETMANN, E.; VALENTE, T.N.P. et al. Evaluation of fecal recovering and long term bias of internal and external markers in a digestion assay with cattle. Revista Brasileira de Zootecnia, v.40, p.174-182, 2011.

SENGER, C.C.D.; KOZLOSKI, G.V.; SANCHEZ, L.M. B. et al., Evaluation of autoclave procedures for fibre analysis in forage and concentrate feedstuffs. Animal Feed Science and Technology, v.146, p.169-174, 2008.

SILVA, D.J.; QUEIROZ, A.C. Análises de alimentos. Métodos químicos e biológicos. 3.ed. Viçosa, MG: Editora UFV, 2002. $235 p$.

SILVEIRA, M. Preparo de amostras biológicas para microscopia eletrônica de varredura. In: SOUZA, W. (Ed.) Técnicas básicas de microscopia eletrônica aplicadas às ciências biológicas. Rio de Janeiro: Sociedade Brasileira de Microscopia Eletrônica, 1998. p.33-44.

UDÉN, P.; PARRA, R.; Van SOEST, P.J. Factors influencing reliability of the nylon bag technique. Journal of Dairy Science, v.57, p.622-622, 1974.

UDÉN, P.; Van SOEST, P.J. Investigation of the in situ bag technique and a comparison of the fermentation in heifers, sheep, ponies and rabbits. Journal of Animal Science, v.58, p.213-221, 1984

VALENTE, T.N.P.; DETMANN, E.; VALADARES FILHO, S.C. et al. Avaliação dos teores de fibra em detergente neutro em forragens, concentrados e fezes bovinas moídas em diferentes tamanhos e em sacos de diferentes tecidos. Revista Brasileira de Zootecnia, 2011 (in press).

Van SOEST, P.J. Nutritional ecology of the ruminant. 2.ed. Ithaca: Cornell University Press, 1994. 476p.

VANZANT, E.S.; COCHRAN, C.; TITGEMEYER, E.C. Standardization of in situ techniques for ruminant feedstuff evaluation. Journal of Animal Science, v.76, p.2717-2729, 1998. 